\title{
Evaluation of Cervical Lymphadenopathy in Children: Is Epstein-Barr Virus Infection Predictable?
}

\author{
๑ Nurhayat Yakut, @ Eda Kepenekli \\ Marmara University Faculty of Medicine, Department of Pediatric Infectious Diseases, Istanbul, Turkey
}

\section{Abstract}

Aim: The aim of this study was to evaluate the paediatric patients with cervical lymphadenopathy (LAP) and to compare the clinical and laboratory features between Epstein-Barr virus (EBV) infections and the other aetiologies.

Methods: We conducted a retrospective, single-center study of paediatric patients with cervical LAP from a tertiary care hospital in Turkey between October 2017 and March 2020. The medical records including demographic information, clinical features and laboratory results were collected from paediatric patients with cervical LAP. Patients were divided into two groups according to whether the aetiology of LAP was EBV infection or the others. Clinical and laboratory findings were compared between the two groups.

Results: A total of 175 patients included in the study. Nonspecific lymphadenitis was the most common diagnosis occurring at a rate of $54.3 \%$. EBV infection was responsible for $17.1 \%$ of all causes. The presence of fever, white blood cell (WBC) and lymphocyte count were significantly higher and LAP size was significantly larger in patients with cervical LAP caused by EBV infection.

Conclusion: Fever, elevated WBC and lymphocyte count may be predictors for EBV infection in children with cervical LAP. In patients who had these features, serological tests for EBV could make a significant contribution to reach an accurate diagnosis without wasting time.

Keywords: Cervical LAP, children, EBV infection

\section{Introduction}

Cervical lymphadenopathy (LAP) is commonly defined as cervical lymph nodes measuring more than $1 \mathrm{~cm}$ in diameter is a common finding on physical examination in children and creates parental anxiety. The prevalence rate is about $38 \%$ to $45 \%$ of otherwise healthy children $(1,2)$. There are too many conditions in the differential diagnosis of cervical LAP. Although the most common causes are bacterial and viral infectious diseases resulting in reactive hyperplasia, malignancies, congenital abnormalities and autoimmune diseases can also be the reason $(3,4)$. One of the primary infectious causes of cervical LAP is EpsteinBarr virus (EBV) infection usually appears in early childhood in developing countries like our country (5). More serious disorders such as malignancy should be excluded rapidly in order to avoid unnecessary investigations and to relieve the parent. The aim of this study was to investigate the demographic, clinical and laboratory characteristics, treatment, and outcomes in children with cervical LAP and to compare the clinical and laboratory features between EBV infections and the other aetiologies.

\section{Methods}

\section{Study Design and Data Collection}

This study was conducted with the approval of the Marmara University Clinical Research Ethics Committee of our hospital (date: January $3^{\text {rd }} 2020$ and decision no: 09.2020.6).

A retrospective single-center study was conducted of paediatric patients with cervical LAP at outpatient clinic and ward of paediatric infectious diseases of tertiary care hospital in Turkey. The medical records were collected from paediatric patients with cervical LAP in our hospital, between October 2017 and March 2020. The following demographic information, clinical features, laboratory results and management data were collected

Yazışma Adresi/Address for Correspondence: Nurhayat Yakut, Marmara University Faculty of Medicine, Department of Pediatric Infectious Diseases, Istanbul, Turkey 
retrospectively: age, gender, LAP size and location, duration of symptoms and antibiotic therapy, previous use of antibiotic therapy, duration of hospital stay, surgical drainage, ultrasonography, computed tomography, magnetic resonance imaging, complete blood count, C-reactive protein, lactate dehydrogenase (LDH), uric acid level, liver function tests, excisional biopsy and final diagnosis.

\section{Definitions}

Enlarged $>10$ millimeters lymph nodes in the cervical region were accepted as cervical LAP.

The diagnosis of primary EBV infection was confirmed in the presence of IgM antibodies to EBV viral capsid antigen.

\section{Statistical Analysis}

Data were entered into Microsoft Office Excel 2010 (Microsoft, Redmond, WA, USA). The statistical analysis was performed using SPSS version 22.0 (IBM, SPSS). Normally distributed data were assessed using means and the Student's t-test. The significance of the nonparametric data was assessed using the Mann-Whitney $U$ test. The statistical significance of the dichotomous outcomes was determined using the chi-square test, Fisher's Exact test, the Fisher-Freeman-Halton test, and Yates's continuity correction. A multivariate logistic regression analysis was performed. A p-value of $<0.05$ was considered statistically significant.

\section{Results}

A total of 175 children with cervical LAP were examined in our hospital between October 2017 and March 2020. Among the 175 patients, 133 (76\%) had received antibiotics before admission. Surgical drainage was who performed in 40 patients (22.8\%). At least one pathogen was identified in 32 of $40(80 \%)$ patients performed surgical drainage. Staphylococcus aureus was the most common organism isolated in 10 (31.2\%) patients, followed by Streptococcus viridans in 8 patients (25\%) and Streptococcus pyogenes in four patients $(12,5 \%)$. Lymph node excisional biopsy was performed in $27(15.4 \%)$ patients. The results of biopsies were as follows: 16 patients (59.2\%) of reactive lymphadenitis, 7 patients of necrotizing granulomatous lymphadenitis, three patients of Hodgkin's lymphoma and one patient of nasopharyngeal carcinoma. The most common cause of cervical LAP was nonspecific lymphadenitis in 95 (54.3\%) patients. In 30 patients (17.1\%), a diagnosis of EBV infection was performed.

The mean white blood cell (WBC) count at the time of admission was 12014.29 \pm 5759.29 (range, 2500-38200) $/ \mathrm{mm}^{3}$. The most LAP localization was the right cervical region in 63 (36\%) patients and 53 (30.3\%) patients had cervical LAP bilaterally. The patient characteristics are summarised in Table 1.

Patients were divided into two groups; patients with cervical LAP caused by EBV infection (Group 1; $\mathrm{n}=30$ ), and patients with cervical LAP caused by the other aetiologies (Group 2; $n=145$ ). Clinical and laboratory findings were compared between the two groups. The male/female ratio was similar between the two groups. Duration of symptoms, antibiotic therapy and hospital stay of the patients were significantly shorter in Group 1 ( $p<0.05)$.

The prevalence of fever, tonsillopharyngitis and hepato/ splenomegaly was found significantly higher in Group 1. Patients with EBV infection had a lower percentage of hospitalization and antibiotic use $(p<0.05)$. According to the univariate analysis, the following laboratory values were significantly higher in Group 1: lymphocyte, granulocyte, WBC count, alanine aminotransferase, aspartate aminotransferase and LDH $(p<0.05)$. Mean lymph node size was $4.32 \pm 0.84 \mathrm{~cm}$ in Group 1 and $2.87 \pm 0.49 \mathrm{~cm}$ in Group 2. Lymph node size in Group 1 was significantly larger than Group $2(p<0.05)$ (Tables 2, 3).

In the multivariate analysis, we detected that WBC, lymphocyte count and prevalence of fever were significantly higher [odds ratio $(O R)=1.000 ; 95 \%$ confidence interval (Cl): 0.999-1.000, OR=1.001; 95\% Cl: 1.000-1.002, $\mathrm{OR}=51,591 ; 95 \% \mathrm{Cl}: 2.225-1169,919$, respectively], and lymph node size was significantly larger ( $O R=30,562 ; 95 \%$ Cl: 4.346-214,925) in Group 1 (Table 4).

\section{Discussion}

Cervical LAP is one of the most common problems in children. It creates anxiety in parents with diverse aetiologies including malignancy (6). EBV infection is also in the differential diagnosis (7). In this study, we tried to investigate pediatric cervical LAP characteristics and detect the difference of cervical LAP caused by EBV from the other aetiologies.

In this study, we detected that among the 175 patients, $108(61.7 \%)$ were male. Similar to our study, previous studies report that cervical LAP is more likely to be seen in boys $(8,9)$. The spectrum of clinical manifestations and findings can vary according to aetiology. A retrospective study by Aykac et al. (4) conducted on children reported that the most frequent symptoms and findings were fever $(45.3 \%)$, tonsillopharyngitis (53\%) and hepatomegaly $(10.3 \%)$. In another study conducted on Sudanese children with cervical LAP, Bilal et al. (10) reported that the most common clinical examination findings were fever $(71.3 \%)$, cough $(57 \%)$, weight loss $(55 \%)$ and sore throat (46.2\%). One of the important reasons for cervical LAP is dental caries resulting in odontogenic infections. Our 


\section{Table 1. The demographic and clinical characteristics of the patients}

\begin{tabular}{|c|c|c|c|}
\hline & & Min-Max & Mean \pm SD (median) \\
\hline Age (years) & & $0.2-18$ & $6.56 \pm 4.48$ \\
\hline Duration of symptoms ${ }_{\text {(median) }}$ & & $2-120$ & $12.42 \pm 13.11(10)$ \\
\hline Duration of antibiotic therapy (day) ${ }_{\text {(median) }}$ & & $0-28$ & $10.36 \pm 7.45(10)$ \\
\hline Duration of hospitalisation (median) & & $0-29$ & $5.11 \pm 7.07(0)$ \\
\hline \multirow{2}{*}{ LAP size $(\mathrm{cm})$} & & $2-6$ & $3.12 \pm 0.78$ (3) \\
\hline & & $\mathbf{n}$ & $\%$ \\
\hline \multirow{2}{*}{ Gender } & Female & 67 & 38.3 \\
\hline & Male & 108 & 61.7 \\
\hline \multirow{6}{*}{ Clinical symptoms and findings } & Fever & 55 & 31.4 \\
\hline & Tonsillopharyngitis & 27 & 15.4 \\
\hline & Limited neck mobility & 20 & 11.4 \\
\hline & Tooth decay & 25 & 14.3 \\
\hline & Odynophagia & 5 & 2.9 \\
\hline & Hepato/splenomegaly & 12 & 6.9 \\
\hline \multirow{2}{*}{ Prior antibiotic treatment } & No & 42 & 24 \\
\hline & Yes & 133 & 76 \\
\hline \multirow{9}{*}{ Final diagnosis } & Pharyngotonsillar infections & 10 & 5.7 \\
\hline & Odontogenic infections & 24 & 13.7 \\
\hline & Non-specific lymphadenitis & 95 & 54.3 \\
\hline & Epstein-Barr virus infection & 30 & 17.1 \\
\hline & Tularemia & 3 & 1.7 \\
\hline & Cat-scratch disease & 2 & 1.1 \\
\hline & Tuberculous lymphadenitis & 7 & 4 \\
\hline & Nasopharyngeal carcinoma & 1 & 0,6 \\
\hline & Hodgkin lymphoma & 3 & 1.7 \\
\hline \multirow{2}{*}{ Hospital unit } & Outpatient & 94 & 53.7 \\
\hline & Inpatient & 81 & 46.3 \\
\hline \multirow{2}{*}{ Excisional biopsy } & No & 148 & 84.6 \\
\hline & Yes & 27 & 15.4 \\
\hline \multirow{4}{*}{ Antibiotic treatment } & No & 50 & 28.6 \\
\hline & Ampicillin-sulbactam & 47 & 26.9 \\
\hline & Ampicillin-sulbactam + clindamycin & 24 & 13.7 \\
\hline & Others & 54 & 30.9 \\
\hline \multirow{2}{*}{ C-reactive protein, $\mathrm{mg} / \mathrm{dL}$} & Negative $(<3 \mathrm{mg} / \mathrm{dL})$ & 82 & 46.9 \\
\hline & Positive (>3 mg/dL) & 93 & 53.1 \\
\hline \multirow{5}{*}{ Imaging modalities } & Ultrasound imaging & 113 & 64.6 \\
\hline & Computed tomography & 4 & 2.3 \\
\hline & USG + CT & 37 & 21.1 \\
\hline & USG + Magnetic resonance imaging & 15 & 8.6 \\
\hline & USG + CT + MRI & 6 & 3.4 \\
\hline \multirow{3}{*}{ LAP localization } & Right & 63 & 36 \\
\hline & Left & 59 & 33.7 \\
\hline & Bilateral & 53 & 30.3 \\
\hline
\end{tabular}


results about the reason for cervical LAP are similar to previous studies.

Several studies confirmed that clinical symptoms and findings lasting more than four weeks may indicate increased risk for malignancy $(8,11,12)$. In accordance with previous studies, we detected that the mean duration of symptoms was $12.42 \pm 13.11$ and only four patients were diagnosed with malignancy. These results suggest that patients with persistent cervical LAP and chronic symptoms may present malignancy and further evaluation may be required for these patients.

Cervical LAP frequently represents a transient response of lymphatic tissue to a benign local or generalized infection, but it can also rarely be caused by other more significant pathology such as malignancy. The most common cause of cervical LAP in children is reactive hyperplasia secondary to known or unknown infectious agents (12). A systematic review of 2687 cervical LAP in paediatric patients showed that the most common cause was nonspecific benign etiology occurring at a rate of $67.8 \%$ (13). In another study, Indolfi et al. (14). reported that among 392 paediatric patients with head and neck LAP, 220 patients (56.1\%) had a history of infection and 101 patients (24.9\%) nonspesific reactive lymphadenitis. Similarly, we found that nonspecific lymphadenitis was the most common cause of cervical LAP.

Bacterial infections resulting in cervical LAP range from aerobic and anaerobic to mycobacterial infections. The most commonly reported microorganisms isolated from suppurative cervical LAP are Staphylococcus aureus, followed by group A streptococcus (Streptococcus pyogenes) and anaerobic bacteria $(12,15)$. Indolfi et al. (14) reported that the most frequently isolated pathogen was $\mathrm{S}$. pyogenes in 31 patients (22.9\%), followed by $\mathrm{S}$. aureus in 10 patients (7.4\%). In accordance with the previous reports, the most commonly isolated pathogen in our study was $S$. aureus. S. viridans was the second most common microorganism. Compared with other studies, we detected a higher incidence of $S$. viridans. The reason for this can be explained by the high number of patients with dental caries.

\begin{tabular}{|c|c|c|c|c|}
\hline & & $\begin{array}{l}\text { EBV lymphadenitis } \\
\text { (Group 1) }\end{array}$ & $\begin{array}{l}\text { Other aetiologies } \\
\text { (Group 2) }\end{array}$ & \multirow[t]{2}{*}{$p$} \\
\hline & & Mean \pm SD (median) & Mean \pm SD (median) & \\
\hline Age (years) & & $5.77 \pm 4$ & $6.73 \pm 4.57$ & ${ }^{1} 0.286$ \\
\hline Duration of symptoms & & $7.23 \pm 5.2(6)$ & $13.5 \pm 13.98(10)$ & ${ }^{2} 0.002^{*}$ \\
\hline Duration of antibiotic therapy (day) ${ }_{\text {(median) }}$ & & $1.33 \pm 3.46(0)$ & $12.23 \pm 6.64(14)$ & ${ }^{2} 0,000^{*}$ \\
\hline \multirow[t]{2}{*}{ Duration of hospitalization (median) } & & $1.27 \pm 2.49(0)$ & $5.91 \pm 7.44(2)$ & ${ }^{2} 0.001^{*}$ \\
\hline & & n (\%) & n (\%) & \\
\hline \multirow{2}{*}{ Gender } & Female & $7(23.3 \%)$ & $60(41.4 \%)$ & ${ }^{3} 0.100$ \\
\hline & Male & $23(76.7 \%)$ & $85(58.6 \%)$ & - \\
\hline \multirow{6}{*}{ Clinical symptoms and findings } & Fever & $23(76.7 \%)$ & $32(22.1 \%)$ & ${ }^{3} 0.000^{*}$ \\
\hline & Tonsillopharyngitis & $17(56.7 \%)$ & $10(6.9 \%)$ & ${ }^{4} 0.000^{*}$ \\
\hline & Limited neck mobility & $5(16.7 \%)$ & $15(10.3 \%)$ & ${ }^{4} 0.241$ \\
\hline & Tooth decay & $0(0 \%)$ & $25(17.2 \%)$ & ${ }^{4} 0.006^{*}$ \\
\hline & Odynophagia & $1(3.3 \%)$ & $4(2.8 \%)$ & ${ }^{4} 0.614$ \\
\hline & Hepato/splenomegaly & $12(40 \%)$ & $0(0 \%)$ & ${ }^{4} 0.000^{*}$ \\
\hline \multirow[t]{2}{*}{ Prior antibiotic treatment } & No & $15(50 \%)$ & $27(18.6 \%)$ & ${ }^{3} 0.001 *$ \\
\hline & Yes & $15(50 \%)$ & $118(81.4 \%)$ & - \\
\hline \multirow{2}{*}{ Surgical drainage } & No & $29(100 \%)$ & $105(72.4 \%)$ & ${ }^{3} 0.003^{*}$ \\
\hline & Yes & $0(0 \%)$ & $40(27.6 \%)$ & - \\
\hline \multirow{2}{*}{ Positive culture } & No & $14(100 \%)$ & $61(65.6 \%)$ & ${ }^{4} 0.005^{*}$ \\
\hline & Yes & $0(0 \%)$ & $32(34.4 \%)$ & - \\
\hline \multirow{2}{*}{ Hospital unit } & Outpatient & $23(76.7 \%)$ & $71(49 \%)$ & ${ }^{3} 0.010^{*}$ \\
\hline & Inpatient & $7(23.3 \%)$ & $74(51 \%)$ & - \\
\hline \multirow{2}{*}{ Excisional biopsy } & No & $30(100 \%)$ & $118(81.9 \%)$ & ${ }^{4} 0.005^{*}$ \\
\hline & Yes & $0(0 \%)$ & $27(18.1 \%)$ & - \\
\hline
\end{tabular}




\begin{tabular}{|c|c|c|c|c|}
\hline & & EBV lymphadenitis (Group 1) & Other aetiologies (Group 2) & \multirow{2}{*}{$\mathbf{p}$} \\
\hline & & Mean \pm SD & Mean \pm SD & \\
\hline White blood cells $/ \mathrm{mm}^{3}$ & & $14546.67 \pm 6702.07(12800)$ & $11490.34 \pm 5424.14(10400)$ & ${ }^{1} 0.009$ * \\
\hline Hemoglobin, g/dL & & $11.91 \pm 1.48(11.7)$ & $11.64 \pm 1.38(11.6)$ & ${ }^{1} 0.595$ \\
\hline Alanine aminotransferase, IU/L & & $117.67 \pm 125.68(67.5)$ & $23.4 \pm 32.93(15)$ & ${ }^{1} 0.000$ * \\
\hline Aspartate aminotransferase, IU/L & & $112.63 \pm 112.56(73)$ & $35.66 \pm 32.39(29)$ & ${ }^{1} 0.000 *$ \\
\hline Uric acid mg/dL & & $3.64 \pm 1.06(3.5)$ & $3.37 \pm 1.05(3.2)$ & ${ }^{1} 0.180$ \\
\hline Lymphocytes $/ \mathrm{mm}^{3}$ & & $8593.33 \pm 4083.35(8500)$ & $3693.79 \pm 1723.58(3400)$ & ${ }^{1} 0.000 *$ \\
\hline Granulocytes before treatment $/ \mathrm{mm}^{3}$ & & $4036.67 \pm 2725.04(3300)$ & $6428.28 \pm 4902.21(5300)$ & ${ }^{1} 0.001^{*}$ \\
\hline Granulocytes after treatment $/ \mathrm{mm}^{3}$ & & $3166.67 \pm 1577.94(3050)$ & $3736.57 \pm 2116.47(3400)$ & ${ }^{1} 0.115$ \\
\hline Lactate dehydrogenase, IU/L & & $408.8 \pm 200.2(352.5)$ & $270.51 \pm 101.09(259)$ & ${ }^{1} 0.000$ * \\
\hline \multirow{2}{*}{ LAP size $(\mathrm{cm})$} & & $4.32 \pm 0.84(4.5)$ & $2.87 \pm 0.49(3)$ & ${ }^{1} 0.000$ * \\
\hline & & n (\%) & n (\%) & \\
\hline \multirow{4}{*}{ Antibiotic treatment } & No & $27(90 \%)$ & $23(15.9 \%)$ & ${ }^{2} 0.000^{*}$ \\
\hline & Ampicillin-sulbactam & $1(3.3 \%)$ & $46(31.7 \%)$ & - \\
\hline & Ampicillin-sulbactam+ Clindamycin & $0(0 \%)$ & $24(16.6 \%)$ & - \\
\hline & Others & $2(6.7 \%)$ & $52(35.9 \%)$ & - \\
\hline \multirow[t]{2}{*}{ C-reactive protein, $\mathrm{mg} / \mathrm{dL}$} & Negative (<3 mg/dL) & $15(50 \%)$ & $67(46.2 \%)$ & ${ }^{3} 0,859$ \\
\hline & Positive (>3 mg/dL) & $15(50 \%)$ & $78(53.8 \%)$ & - \\
\hline \multirow{5}{*}{ Imaging modalities } & Ultrasound imaging & $27(90 \%)$ & $86(59.3 \%)$ & ${ }^{4} 0.033^{*}$ \\
\hline & Computed tomography & $0(0 \%)$ & $4(2.8 \%)$ & - \\
\hline & USG + CT & $3(10 \%)$ & $34(23.4 \%)$ & - \\
\hline & USG + MRI & $0(0 \%)$ & $15(10.3 \%)$ & - \\
\hline & USG + CT + MRI & $0(0 \%)$ & $6(4.1 \%)$ & - \\
\hline \multirow{3}{*}{ LAP localization } & Right & $6(20 \%)$ & $57(39.3 \%)$ & ${ }^{20} 0.000$ * \\
\hline & Left & $4(13.3 \%)$ & $55(37.9 \%)$ & - \\
\hline & Bilateral & $20(66.7 \%)$ & $33(22.8 \%)$ & - \\
\hline
\end{tabular}

${ }^{1}$ Mann-Whitney U Test, ${ }^{2}$ Chi-square test, ${ }^{3}$ Yates's continuity correction, ${ }^{4}$ Fisher Freeman Halton Test, LAP: Lymphadenopathy, USG: Ultrasound imaging, CT: Computed tomography, MRI: Magnetic resonance imaging, SD: Standard deviation, EBV: Epstein-Barr virus

\begin{tabular}{|c|c|c|c|}
\hline & OR & $95 \% \mathrm{Cl}$ & $p$ \\
\hline White blood cells & 1.000 & $0.999-1.000$ & $0.034^{*}$ \\
\hline Lymphocytes & 1.001 & $1.000-1.002$ & $0.001 *$ \\
\hline LAP size & 30.562 & $4.346-214.925$ & $0.001^{*}$ \\
\hline Fever & 51.591 & 2.225-1169.919 & $0.013^{*}$ \\
\hline Constant & 0.000 & - & $0.000 *$ \\
\hline \multicolumn{4}{|c|}{$\begin{array}{l}\text { EBV: Epstein-Barr virus, OR: Odds ratio, Cl: Confidence interval, LAP } \\
\text { Lymphadenopathy }\end{array}$} \\
\hline
\end{tabular}

Many viruses, including EBV, may cause a self-limited and uncomplicated cervical LAP in children. In large cohort studies with paediatric patients, rate of cervical LAP caused by EBV was reported as $15 \%$ Abdel-Aziz et al. (7), $8.8 \%, \%$ by Deosthali et al. (13) and $32.7 \%$ by Sarsu et al. (16) In addition, Bozlak et al. (9) and Indolfi et al. (14) demonstrated that EBV was responsible for $27 \%$ and 29.6 of infectious causes of cervical LAP, respectively. A cross-sectional study by Bilal JA conducted on 82 children with cervical LAP reported that EBV infection was diagnosed in 13 (15.9\%) patients (17). These different rates can be caused by different study designs, including different geographic regions and age groups. In our study, EBV infection was serologically diagnosed in 30 (17.1\%) patients with cervical LAP.

Determining diagnostic pathway for patients with cervical LAP is difficult because of broad differential diagnoses. The differential diagnosis of cervical LAP includes many viral infectious diseases such as EBV infection. Some symptoms and findings may guide the differential diagnosis. A recent history of upper respiratory tract infection, dental caries and fluctuation suggest a reactive process $(18,19)$. Weight loss, lymph nodes more than $2.5 \mathrm{~cm}$ in size being hard and fixed to the underlying tissue, multiple sites of LAP have been 
associated with a higher risk of malignancy (20-23). We think that determining clinical and laboratory predictors of EBV may be helpful to differential diagnosis and prevent unnecessary investigations and medical procedures. In this study, we found that WBC, lymphocyte count, liver enzymes, prevalence of fever, tonsillopharyngitis and hepato/splenomegaly were significantly higher and LAP size was significantly larger in children with cervical LAP caused by EBV than the other aetiologies. These results are similar to previous studies conducted on children with cervical $\operatorname{LAP}(7,17,24-27)$. When patients have these symptoms or findings, a serologic assay for EBV may be warranted to help with the diagnostic evaluation on the first step.

\section{Study Limitations}

The important limitations of this study were its retrospective, single-center design and relatively small sample size.

\section{Conclusion}

Our study determined that there were independent association between fever, elevated WBC, lymphocyte count, lymph node size and cervical LAP caused by EBV infection. The presence of these features may be warning sign for EBV and serological tests for EBV specific IgM and IgG antibodies can take place in the first step for differential diagnosis in these patients.

\section{Authorship Contributions}

Concept: N.Y., E.K., Design: N.Y., E.K., Data Collection or Processing: N.Y., Analysis or Interpretation: N.Y., E.K., Literature Search: N.Y., Writing: N.Y., E.K.

Conflict of Interest: The authors declare that they have no conflict of interest.

Financial Disclosure: No financial support was received.

\section{References}

1. Genc B. Çocukluk Çağında Lenfadenopatilere Yaklaşım. Approach to Childhood Lymphadenopathy. The Journal of Pediatric Research 2014;1:6-12.

2. Rajasekaran K, Krakovitz P. Enlarged neck lymph nodes in children. Pediatr Clin North Am 2013;60:923-36.

3. Stutchfield CJ, Tyrrell J. Evaluation of lymphadenopathy in children, Paediatr Child Health 2012;22:98-102.

4. Aykac K, Ozsurekci Y, Basaranoglu ST, et al. Çocuklarda lenfadenopati nedenleri: Hacettepe Üniversitesi enfeksiyon hastalıkları deneyimi 2015-2016. Türkiye Çocuk Hast Derg/ Turkish J Pediatr Dis 2016;59:155-60.

5. Topp SK, Rosenfeldt V, Vestergaard H, Christiansen CB, MarieLouise Von Linstow ML. Clinical characteristics and laboratory findings in Danish children hospitalized with primary EpsteinBarr virus infection. Infect Dis (Lond) 2015;47:908-14.

6. Özyörük D, Çay Ü. Servikal Lenfadenopatili Olgularımızın Retrospektif Değerlendirilmesi. The Retrospective Evaluation of Our Cervical Lymphadenopathy Cases. Türkiye Çocuk Hast Derg/Turkish J Pediatr Dis 2018;12:94-7.

7. Abdel-Aziz M, El-Hoshy $H$, Rashed M, Qotb M, Awad S, Naguib N. Epstein-Barr virus infection as a cause of cervical lymphadenopathy in children. Int J Pediatr Otorhinolaryngoln 2011;75:564-7.

8. Oguz A, Karadeniz C, Temel EA, Citak EC, Okur FV. Evaluation of peripheral lymphadenopathy in children. Pediatr Hematol Oncol 2006;23:549-61.

9. Bozlak S, Varkal MA, Yildiz I, et al. Cervical lymphadenopathies in children: A prospective clinical cohort study. Int J Pediatr Otorhinolaryngol 2016;82:81-7.

10. Bilal JA, Elshibly EM. Etiology and clinical pattern of cervical lymphadenopathy in Sudanese children. Sudan J Paediatr 2012;12:97-103.

11. Özkale $Y$, Özkale $M$, Sipahi T. Çocukluk Çağında Periferik Lenfadenopatiler: Tek Merkezli Çalışma. Peripheral Lymphadenopathy in Childhood: Single Center Study. Cukurova Medical Journal 2015;40:418-29.

12. Weinstock MS, Patel NA, Smith LP. Pediatric Cervical Lymphadenopathy. Pediatr Rev 2018;39:433-43.

13. Deosthali A, Donches K, DelVecchio M, Aronoff $S$. Etiologies of Pediatric Cervical Lymphadenopathy: A Systematic Review of 2687 Subjects. Glob Pediatr Health 2019;6:2333794X19865440.

14. Indolfi P, Perrotta S, Rossi F, et al. Childhood Head and Neck Lymphadenopathy: A Report by a Single Institution (20032017). J Pediatr Hematol Oncol 2019;41:17-20.

15. Varkal MA, Yıldız I, Unuvar E. Çocukluk çağında lenfadenopatıye yaklaşım. Management of lymphadenopathy in childhood. İst Tıp Fak Derg /J Ist Faculty Med 2015;78:517.

16. Sarsu SB, Sahin K. A retrospective evaluation of lymphadenopathy in children in a single center's experience. J Pak Med Assoc 2016;66:654-7.

17. Bilal JA. Prevalence and Clinical Characteristics of Primary Epstein-Barr Virus Infection Among Children Presented with Cervical Lymphadenopathy. J Clin Diagn Res 2015;9:8-10.

18. Aydogdu S, Yılmaz TG, Tugcu D. Lenfadenopatiye Yaklaşım: Vaka Sunumu ve Literatürün Gözden Geçirilmesi. Çocuk Dergisi 2015;15:118-23.

19. Eyibilen A, Ekinci A, Aladag I. Servikal lenfadenit nedeni olarak tularemi. Tularemia as a cause of cervical lymphadenitis. Dicle Tıp Derg / Dicle Med J 2011;38: 76-8.

20. Nolder AR. Paediatric cervical lymphadenopathy: when to biopsy? Curr Opin Otolaryngol Head Neck Surg 2013;21:56770. 
21. Locke R, MacGregor F, Kubba H. The validation of an algorithm for the management of paediatric cervical lymphadenopathy. Int J Pediatr Otorhinolaryngol 2016;81:5-9.

22. Unsal O, Soytas P, Hascicek SO, Coskun BU. Clinical approach to pediatric neck masses: Retrospective analysis of 98 cases. North Clin Istanb 2017:4:225-32.

23. Gul M, Aliosmanoglu I, Turkoglu A, et al. Erişkin çağı periferik lenfadenopatileri: Eksizyonel biyopsi uygulanan 67 hastanın sonuçları. Peripheral lymphadenopathy in adults: Results of 67 cases of excisional biopsy. Dicle Tıp Derg / Dicle Med J 2013;40: 245-9.

24. Çaglar I, Topal S, Çokboz M, et al. Clinical features and laboratory findings in children hospitalized with acute Epstein-
Barr virus infection: a crosssectional study in a tertiary care hospital. Turk J Pediatr 2019;61:368-73.

25. Macsween KF, Higgins CD, McAulay KA, et al. Infectious mononucleosis in university students in the United kingdom: evaluation of the clinical features and consequences of the disease. Clin Infect Dis 2010;50:699-706.

26. Gaddey HL, Riegel AM. Unexplained Lymphadenopathy: Evaluation and Differential Diagnosis. Am Fam Physician 2016;94:896-903.

27. Riva G, Sensini M, Peradotto F, Scolfaro C, Di Rosa G, Tavormina P. Pediatric neck masses: how clinical and radiological features can drive diagnosis. Eur J Pediatr 2019;178:463-71. 